Metody analizy danych

\author{
Marta Targaszewska \\ Katedra Ekonometrii \\ Uniwersytet Ekonomiczny we Wrocławiu
}

\title{
Metody pomiaru jakości kształcenia na uczelniach wyższych
}

\section{Streszczenie}

Celem pracy jest przedstawienie wybranych metod pomiaru jakości kształcenia na uczelniach wyższych na podstawie danych marketingowych. Artykuł składa się z dwóch części. W pierwszej w sposób syntetyczny przedstawiono pojęcie jakości i jakości usług edukacyjnych na poziomie wyższym. W drugiej części zaprezentowano metody jej pomiaru z wykorzystaniem modelu SERVQUAL i techniki IPA oraz możliwości aplikacyjnych obu metod na przykładzie Uniwersytetu Ekonomicznego we Wrocławiu.

Słowa kluczowe: jakość usług edukacyjnych, edukacja na poziomie wyższym, SERVQUAL, IPA.

\section{Wprowadzenie}

Jakość kształcenia na uczelniach wyższych jest jednym z ważniejszym problemów, jakim zajmuje się środowisko akademickie zarówno w Polsce i w Europie, jak i na całym świecie. W Europie ważność problemu podkreślają m.in. deklaracja bolońska, będąca podstawą procesu mającego na celu stworzenie zintegrowanego i konkurencyjnego systemu szkolnictwa wyższego, oraz strategia lizbońska, mająca zapewnić trwały i zrównoważony wzrost gospodarczy przez inwestycje w kapitał ludzki, a więc w wykształcenie. Jakość jest zatem nie tylko gwarantem podniesienia konkurencyjności jednostki akademickiej, ale ma również wpływ na całe społeczeństwo: przez inwestycje w kapitał ludzki, 
przygotowanie absolwentów do sprostania potrzebom rynku pracy, a co za tym idzie - zmniejszenie bezrobocia [Jakość w badaniach... 2007, s. 452]. Dlatego też jakość kształcenia na uczelniach wyższych powinna podlegać procesowi zarządzania, który stanowi całokształt usystematyzowanych działań i procedur dotyczących zapewnienia jakości. Jednym z elementów zarządzania jest ciągła kontrola (pomiar) zjawiska. Celem pracy jest prezentacja dwóch wybranych metod pomiaru jakości usług edukacyjnych - modelu SERVQUAL i techniki IPA, oraz wyników badań uzyskanych z ich wykorzystaniem.

\section{Pojęcie jakości usług edukacyjnych}

Jakość, zgodnie z definicją zawartą w normach ISO 9000:2000, rozumiana jest jako stopień, w jakim zbiór inherentnych właściwości spełnia wymagania. Postrzegana jest również jako doskonałość, właściwość albo wartość określonego przedmiotu lub zjawiska. Stanowi ona sumę cech wytworu, wyrobu bądź samego działania [Hamrol 2007, s. 19].

Jakość usług kształcenia wyższego jest natomiast definiowana jako poziom, w jakim spełnione są oczekiwania klientów, a więc studentów, ich rodziców, ich przyszłych pracodawców oraz pracowników dydaktycznych [Sztejnberg i Stypułkowska 2005]. Może być ona rozumiana także jako różnica między oczekiwaniami klienta a tym, co otrzymał [Kolman 2009, s. 19]. Jakość usług kształcenia wyższego może być również postrzegana jako stopień spełnienia założonych przez instytucję akademicką celów, które są związane z procesem kształcenia [Jakość w badaniach... 2007, s, 452]. Ponadto może być poddana ocenie zewnętrznej, wykorzystującej obiektywne kryteria [Przybylski, Rudnicki i Szwed 2010, s. 22].

Jakość usług edukacyjnych determinowana jest przez następujące czynniki: cechy studenta, nauczanie i uczenie się, wyniki, zasoby oraz kontekst. Każdy z nich posiada składniki szczegółowe. Do składników cech studenta można zaliczyć zdolność, wytrwałość oraz chęć do nauki. Drugą grupę reprezentują stosowane metody nauczania, liczba zajęć, sposób oceny pracy studentów oraz wielkość grup ćwiczeniowych bądź laboratoryjnych. Na wyniki składają się korzyści społeczne, jak również twórcze i emocjonalne umiejętności. Zasoby obejmują środki materialne (materiały dydaktyczne, wydawnictwa dostępne w bibliotece) oraz zasoby ludzkie (kadra naukowo-dydaktyczna, zarządzająca, administracyjna). Ostatni czynnik obejmuje wiele składników, takich jak: warunki ekonomiczne, czynniki społeczne, kulturalne, religijne, wiedzę i umiejętności nauczycieli czy też możliwość współpracy szkoły z organizacjami pozauczelnianymi [Sztejnberg 2008, s. 18-19].

Instytucja akademicka powinna nieustannie polepszać jakość swoich usług. Aby było to możliwe, powinna regularnie dokonywać pomiarów jej poziomu oraz 
oceny swojego funkcjonowania na dwóch płaszczyznach [Przybylski, Rudnicki i Szwed 2010, s. 25]: 1) klientów - ocena kompetencji zdobytych w trakcie nauki (przeprowadzana przez studentów i ich rodziców), ocena umiejętności absolwentów danej szkoły wyższej (przeprowadzona przez pracodawców); 2) szkoły wyższej - realizowana przez zewnętrzne instytucje lub samą uczelnię (samodzielnie lub pod kontrolą organizacji zewnętrznej).

\section{Modele i techniki pomiaru jakości usług}

Pierwszym zaprezentowanym sposobem pomiaru jakości usług edukacyjnych jest model jakości opracowany w 1985 r. przez A. Parasuramana, V.A. Zeithaml i L. Berry'ego [1985, s. 41-50]. Jego ideą jest postrzeganie jakości usługi jako funkcji rozbieżności pomiędzy oczekiwaniami klientów a ich percepcją usługi [Parasuraman, Zeithaml i Berry 1990, s. 23]. Podstawowym założeniem oceny usługi edukacyjnej jest istnienie pięciu luk [Łuczak i Matuszak-Flejszman 2007, s. 343-344]:

1) rozbieżności między tym, czego klient oczekuje, a tym, co dostawca usługi - uczelnia, uważa za ważne i satysfakcjonujące dla niego,

2) sprzeczności między postrzeganiem przez kierownictwo szkoły (rektor, dziekani) oczekiwań usługobiorców a cechami fizycznymi usługi,

3) różnica między wymaganiami jakości usługi a usługą faktycznie dostarczoną,

4) sprzeczności między usługą dostarczoną a obiecaną,

5) rozbieżności między oczekiwaniami słuchaczy związanymi ze studiowaniem a jego rzeczywistym postrzeganiem; do jej powstania przyczyniają się wszystkie wyżej wymienione luki.

Najczęściej obiektem badań jest ostatnia luka. W pomiarze jej wielkości wykorzystuje się metodę SERVQUAL [Sagan 2003].

Metoda SERVQUAL została opracowana w 1988 r. przez twórców modelu jakości. Uwzględnia ona wykorzystanie dwuczęściowego kwestionariusza badawczego, za pomocą którego odbiorcy przekazują informacje odnoszące się do oczekiwań (część pierwsza) i postrzegania (część druga) usługi aktualnie świadczonej [Sztejnberg i Stypułkowska 2005]. Ankieta zawiera pytania (po równej liczbie dla percepcji i oczekiwań) dotyczące obszarów mających najistotniejszy wpływ na jakość usługi (tzw. kryteria jakości). W modelu SERVQUAL podstawowymi kryteriami są: warunki materialne, niezawodność obsługi, odpowiedzialność i chęć współpracy, kompetencje pracowników oraz empatia. W pomiarze jakości usług edukacyjnych na poziomie wyższym warunki materialne stanowią wygląd uczelni i jej pomieszczeń, a także jej zasoby kadrowe i rzeczowe - wyposażenie 
sal dydaktycznych. Niezawodność wyraża się przez umiejętność dokładnego, sumiennego i solidnego świadczenia usługi kształcenia - nauczania, jak również dokładne oraz należyte wypełnianie obowiązków przez wykładowców. Odpowiedzialność to szybkość reakcji na oczekiwania i prośby studentów, dostrzeganie przez kadrę akademicką problemów, które ich nurtują, oraz gotowość udzielenia im pomocy. Wiedza i umiejętności niezbędne do wykonania usługi, biegłość, umiejętność zdobycia zaufania studentów są wyrazem kompetencji. Ostatnie kryterium - empatia, to uprzejmość, utożsamianie się z potrzebami odbiorców, troska o nich, szacunek i sympatia im okazywane [Bugdol 2008, s. 210].

Odpowiedzi udzielane są za pomocą siedmiostopniowej skali Likerta, zgodnie z którą nota 1 oznacza, że klient zdecydowanie nie zgadza się z przedstawionym stwierdzeniem, a 7 oznacza, że zdecydowanie się z nim zgadza [Choudhury 2011].

Poziom jakości oceniony metodą SERVQUAL można sprowadzić do następującego wzoru [Sagan 2003]:

gdzie:

$$
S=\sum_{i=1}^{k} p_{i}-e_{i},
$$

$S$ - subiektywne zadowolenie z usługi,

$p_{i}$ - ocena postrzegania danego atrybutu usługi $i$,

$e_{i}$ - ocena oczekiwań klienta co do danego atrybutu usługi,

$k$ - liczba pytań.

Subiektywne zadowolenie klienta można interpretować następująco [Sztejnberg, Stypułkowska i Hurek 2005]:

- poziom otrzymanej usługi jest równy poziomowi pożądanemu, gdy $S=0$,

- postrzegany poziom usługi jest niższy od oczekiwanego, gdy $S<0$,

- poziom świadczonej usługi jest wyższy od oczekiwanego, gdy $S>0$.

Wykorzystane narzędzie pomiaru w metodzie SERVQUAL powinno podlegać ocenie rzetelności, a więc badaniu poziomu skorelowania między sobą wymiarów wchodzących w skład kwestionariusza badawczego lub danego kryterium [Sztejnberg, Stypułkowska i Hurek 2005]. Najczęściej stosowaną techniką pomiaru jest współczynnik $\alpha$-Cronbacha wyrażony wzorem [Brzeziński 2004, s. 475]:

$$
\alpha=\frac{k}{k-1}\left[\frac{\operatorname{var}_{c}-\sum_{i=1}^{k} v a r_{i}}{\operatorname{var}_{c}}\right],
$$

gdzie:

$k$ - liczba kryteriów w danym kwestionariuszu,

$v a r_{c}$ - wariancja całkowita wyników wszystkich kryteriów,

var $_{i}$ - wariancja $i$-tego kryterium. 
Współczynnik $\alpha$-Cronbacha przyjmuje wartości z przedziału od 0 do 1 ; 0 świadczy o braku wyniku prawdziwego, zaś 1 informuje o tym, że wszystkie pozycje są doskonale rzetelne (prawdziwe).

Przedstawiona powyżej skala SERVQUAL umożliwia określenie poziomu zadowolenia klienta. Dzięki niej szkoły wyższe mają możliwość wskazania obszarów wymagających określonych działań naprawczych oraz jasnych standardów jakości. Skala daje również możliwość badania efektywności wprowadzonych zmian przez badanie satysfakcji studentów przed ich wprowadzeniem i po ich wprowadzeniu.

Metodą często stosowaną w pomiarze jakości usługi i satysfakcji klienta jest również metoda importance-performance analysis (IPA), którą zaproponowali w 1977 r. J.A. Martilla i J.C. James. Jako narzędzie badawcze wykorzystuje ona kwestionariusz, w którym klienci oceniają według następujących kryteriów: 1) ważności cech usługi uznanych za istotne, 2) postrzegania przez klienta osiągnięć organizacji w zakresie cech kluczowych [Martilla i James 1977, s. 77-79].

Podobnie jak w modelu SERVQUAL odpowiedzi zarówno w przypadku ważności (1 - nieważny, 7 - bardzo ważny), jak i osiągnięć (1 - niezadowolony, 7 - bardzo zadowolony) udzielane są z wykorzystaniem siedmiostopniowej skali Likerta [Sztejnberg 2008].

Otrzymane wyniki - wartości ocen ważności i spostrzeżeń dotyczących osiągnięć w pierwszym kroku - porządkuje się jako: niskie, średnie lub wysokie.

Kolejny krok to ich prezentacja na dwuwymiarowym wykresie, gdzie oś rzędnych odpowiada średniej ważności, zaś oś odciętych średnim osiągnięciom. Punktem przecięcia obu osi jest wartość centralna wyników (najczęściej średnia arytmetyczna lub mediana) ważności i osiągnięć dla wszystkich cech [Kitchroen 2004]. Graficzne przedstawienie wyników kwestionariusza badawczego jest niezbędne do formułowania strategii organizacji akademickiej. Interpretacja wyników zależy od ćwiartki, w której leży wynik dla danej cechy. Ćwiartka pierwsza („kontynuuj dobrą pracę”) obejmuje cechy, które według klientów są ważne przy podejmowaniu decyzji o skorzystaniu z usługi kształcenia wyższego i dla których spostrzeżenia dotyczące osiągnięć są oceniane wysoko. Uczelnia, której cechy są w tej grupie, powinna utrzymywać dotychczasowe wyniki. Cechy znajdujące się w ćwiartce drugiej (,skoncentruj się na tym”) są ważne w podejmowaniu decyzji o skorzystaniu z usługi kształcenia na poziomie wyższym, ale ocena osiągnięć instytucji akademickiej nie jest wysoka. Zalecane jest skoncentrowanie się na przymiotach umiejscowionych w tej części matrycy. Cechy znajdujące się w ćwiartce trzeciej (,niski priorytet”) reprezentują niski poziom ważności i niski poziom osiągnięć - poniżej średniej. Nie wymagają one jednak bezpośredniej uwagi. Ostatnia, czwarta ćwiartka (,możliwa przesada w ulepszaniu”) obejmuje cechy, które są dla klientów mało istotne przy jednoczesnej wysokiej ocenie 
dotychczasowych osiągnięć. Zaleceniem dla szkół wyższych mających cechy leżące w tej ćwiartce jest podejmowanie działań w celu zapewnienia ich większej ważności [Sztejnberg 2008, s. 113-114]. Rzetelność pomiaru, podobnie jak w przypadku metody SERVQUAL, mierzy się współczynnikiem $\alpha$-Cronbacha.

\section{Rezultaty przeprowadzonych badań}

Aby uzyskać opinię dotyczącą pożądanego i aktualnego poziomu świadczenia usługi edukacyjnej, w pierwszym etapie przeprowadzono ankietę wśród 29 losowo wybranych studentów drugiego roku zarządzania na Wydziale Zarządzania Informatyki i Finansów Uniwersytetu Ekonomicznego we Wrocławiu. Kwestionariusz opracowano zgodnie z procedurą zaproponowaną przez twórców metody SERVQUAL. Obejmował on po 22 stwierdzenia odnoszące się do oczekiwań i percepcji studentów. Pytania dotyczyły każdego z kryterium. W kolejnym etapie zbadano rzetelność zebranych danych zarówno dla całego kwestionariusza, jak i dla każdego kryterium z osobna. Wyniki przedstawiono w tabeli 1.

Tabela 1. Wartości współczynnika rzetelności $\alpha$-Cronbacha w rozróżnieniu na poszczególne kryteria

\begin{tabular}{|l|c|c|c|}
\hline \multicolumn{1}{|c|}{ Kryterium } & Poziom pożądany & Poziom obserwowany & $\begin{array}{c}\text { Poziom według } \\
\text { modelu SERVQUAL }\end{array}$ \\
\hline Warunki materialne & 0,50 & 0,77 & 0,68 \\
\hline Niezawodność & 0,62 & 0,80 & 0,67 \\
\hline Odpowiedzialność & 0,69 & 0,79 & 0,79 \\
\hline Kompetencje & 0,68 & 0,75 & 0,77 \\
\hline Empatia & 0,89 & 0,84 & 0,88 \\
\hline Ogółem & 0,91 & 0,94 & 0,93 \\
\hline
\end{tabular}

Źródło: opracowanie własne na podstawie zebranych danych.

Na podstawie danych tabeli 1 można wnioskować, że jedynie w przypadku kryterium dotyczącego warunków materialnych dla poziomu pożądanego wartość współczynnika rzetelności jest niewystarczająca $(0,50)$. Dla pozostałych kryteriów wartości współczynnika $\alpha$-Cronbacha kształtują się powyżej 0,60 , co świadczy o jednorodności tych grup stwierdzeń. Ponadto wartości $\alpha$-Cronbacha dla wszystkich pytań wchodzących w skład kwestionariusza na każdym z poziomów są wysokie i wynoszą ponad 0,90 . 
Następnie obliczono średnie arytmetyczne dla wyników różnic pomiędzy poziomem obserwowanym a pożądanym. Przyjęto też, że wagi dla każdego kryterium są jednakowe.

Tabela 2. Średnie arytmetyczne dotyczące wyników różnic pomiędzy poziomem obserwowanym a pożądanym dla poszczególnych kryteriów

\begin{tabular}{|l|c|}
\hline \multicolumn{1}{|c|}{ Kryterium } & Średnia \\
\hline Warunki materialne & $-1,95$ \\
\hline Niezawodność & $-2,31$ \\
\hline Odpowiedzialność & $-2,40$ \\
\hline Kompetencje & $-2,30$ \\
\hline Empatia & $-2,23$ \\
\hline
\end{tabular}

Źródło: opracowanie własne na podstawie zebranych danych.

Tabela 3. Wyniki różnic pomiędzy poziomem obserwowanym a pożądanym dla poszczególnych atrybutów

\begin{tabular}{|l|c|}
\hline \multicolumn{1}{|c|}{ Atrybut } & Wynik \\
\hline Schludny wygląd & $-0,66$ \\
\hline Przyjazne podejście & $-1,69$ \\
\hline Dostrzeganie problemów & $-2,03$ \\
\hline Biegłość w fachu & $-2,10$ \\
\hline Uprzejmość & $-2,17$ \\
\hline Rzetelność & $-2,17$ \\
\hline Atrakcyjne sale dydaktyczne & $-2,21$ \\
\hline Zaufanie & $-2,21$ \\
\hline Dokładność i skrupulatność & $-2,21$ \\
\hline Solidność & $-2,28$ \\
\hline Sumienność & $-2,31$ \\
\hline Otwartość & $-2,31$ \\
\hline Życzliwość & $-2,34$ \\
\hline Skuteczność & $-2,38$ \\
\hline Wyposażenie sal & $-2,41$ \\
\hline Okazywanie uwagi & $-2,41$ \\
\hline Pomoc & $-2,45$ \\
\hline Obowiązkowość & $-2,48$ \\
\hline Pomoce naukowe w salach dydaktycznych & $-2,52$ \\
\hline Zrozumienie potrzeb & $-2,52$ \\
\hline Szybkość reakcji & $-2,79$ \\
\hline
\end{tabular}

Źródło: opracowanie własne na podstawie zebranych danych. 
Analizując dane tabeli 2, można stwierdzić, że najwyżej oceniono warunki materialne, ale ich pomiar był nierzetelny. W przypadku pozostałych kryteriów wyniki nieznacznie się od siebie różniły i mieściły się w przedziale od $-2,40$ do $-2,23$. Ogólny wynik dla wszystkich pytań ukształtował się na poziomie $-2,24$. Rezultaty dla poszczególnych atrybutów przedstawia tabela 3, w której wyniki uporządkowano według malejącego poziomu satysfakcji.

Na podstawie danych tabeli 3 można stwierdzić, że żaden z atrybutów nie spełnił oczekiwań studentów biorących udział w badaniach. Najniższej oceniona została szybkość reakcji prowadzących zajęcia, najwyżej zaś ich schludny wygląd oraz przyjazne podejście. Wysoko ocenione zostały również uprzejmość oraz dostrzeganie problemów przez nauczycieli akademickich, a także biegłość w fachu i rzetelność.

W celu rozpoznania słabych i mocnych stron organizowanych zajęć na Uniwersytecie Ekonomicznym we Wrocławiu przepytano 17 losowo wybranych studentów drugiego roku Wydziału Zarządzania, Informatyki i Finansów oraz uczestniczących w zajęciach prowadzonych przez tego samego nauczyciela akademickiego. Studenci udzielali odpowiedzi na 26 pytań dotyczących ważności określonych atrybutów i ich osiągnięć. Podobnie jak w modelu SERVQUAL zebrane dane poddano analizie rzetelności. Obliczono współczynnik $\alpha$-Cronbacha, który dla pytań dotyczących ważności i osiągnięć wyniósł odpowiednio 0,65 i 0,81. Następnie oszacowano średnie arytmetyczne dotyczące wszystkich aspektów, do których odnosiły się pytania zawarte w kwestionariuszu. Atrybuty oraz wyniki badań w podziale na ważność i osiągnięcia przedstawia tabela 4.

Tabela 4. Wyniki analizy IPA dla poszczególnych atrybutów

\begin{tabular}{|l|c|c|}
\hline \multicolumn{1}{|c|}{ Atrybut } & Osiągnięcia & Ważność \\
\hline Zrozumiały cel przedmiotu & 6,00 & 6,06 \\
\hline Zrozumiała treść kształcenia & 6,28 & 5,67 \\
\hline Jasno postawione wymagania & 6,39 & 6,50 \\
\hline Spójność zajęć & 5,78 & 6,06 \\
\hline Zrozumiały materiał & 5,67 & 6,44 \\
\hline Uczestniczenie w zajęciach z entuzjazmem & 5,50 & 5,83 \\
\hline Ciekawe treści & 5,72 & 5,83 \\
\hline Materiał prezentowany w jasny sposób & 6,44 & 6,50 \\
\hline Logiczne uporządkowanie poruszanych zagadnień & 6,44 & 6,06 \\
\hline Odpowiednia ilość materiału & 6,39 & 6,33 \\
\hline Motywowanie do pracy & 6,06 & 5,89 \\
\hline Wiedza prowadzącego & 6,89 & 7,00 \\
\hline Pomoc ze strony prowadzącego & 6,94 & 6,56 \\
\hline
\end{tabular}

Źródło: opracowanie własne na podstawie zebranych danych oraz [Lewis 2004]. 
Otrzymane wyniki zostały również zrzutowane na układ współrzędnych (rys. 1), gdzie punkt przecięcia osi wyznaczono na podstawie średnich arytmetycznych dla osiągnięć i ważności. Wartości średnich wyniosły odpowiednio 6,19 i 6,21.

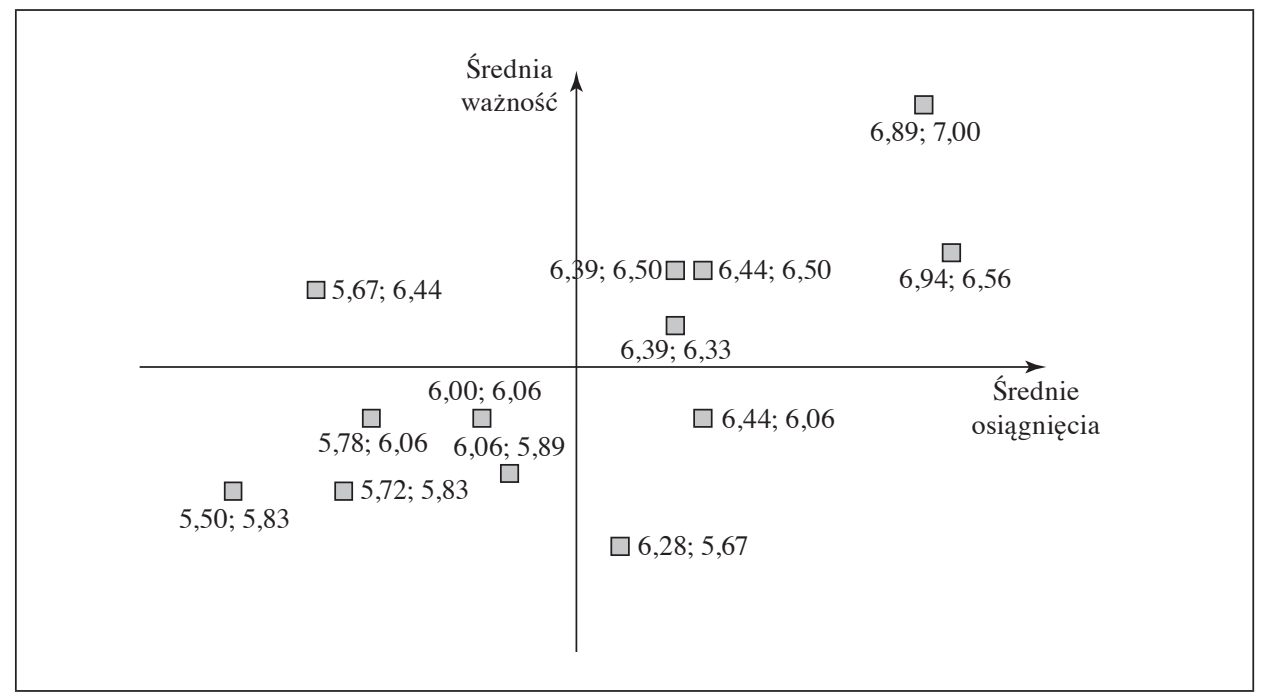

Rys. 1. Siatka IPA

Źródło: opracowanie własne na podstawie zebranych danych.

Jak wynika z analizy rys. 1, w pierwszej ćwiartce („kontynuuj dobrą pracę”) znajdują się takie atrybuty, jak: wiedza prowadzącego, jasny sposób prezentowania materiału, pomoc ze strony prowadzącego, jasno postawione wymagania, a także odpowiednia ilość materiału. Są one ważne dla studentów oraz jednocześnie wysoko przez nich oceniane. Równie wysoko oceniane są logiczne uporządkowanie poruszanych zagadnień i zrozumiała treść kształcenia, ale ich ważność jest oceniana nisko i nie wymagają one bezpośredniej uwagi. Obserwacji nie wymagają również takie mało ważne atrybuty, jak: zrozumiały cel przedmiotu, spójność zajęć, uczestniczenie w zajęciach z entuzjazmem, ciekawe treści przedmiotu oraz motywowanie do pracy. Najwięcej uwagi i pracy wymaga cecha znajdująca się w ćwiartce drugiej - zrozumienie materiału, i to na niej powinien się koncentrować prowadzący zajęcia.

\section{Zakończenie}

Zastosowane metody pozwoliły ocenić satysfakcję wybranych studentów Uniwersytetu Ekonomicznego we Wrocławiu oraz wskazać mocne i słabe strony 
badanej uczelni. Pierwsza zaprezentowana metoda pozwoliła na wykazanie wielkości luki pomiędzy obserwowanym a pożądanym poziomem cech mających wpływ na jakość świadczonych usług. $Z$ analizy wynika, że na poziomie zarówno kryteriów, jak i pojedynczych pytań oczekiwania przewyższają aktualną ocenę określonych atrybutów. Druga metoda pozwoliła na ujawnienie, nad którymi z aspektów decydujących o jakości usługi należy pracować, a które są wystarczająco dobrze postrzegane przez studentów. W obu badaniach wysoko oceniono wiedzę prowadzących oraz ich rzetelność. Najsłabiej oceniono szybkość reakcji nauczycieli akademickich na prośby studentów, która może mieć istotny wpływ na trudności ze zrozumieniem materiału, co wykazano za pomocą techniki IPA. Są to więc atrybuty, nad którymi trzeba pracować, aby zwiększać satysfakcję klientów badanej uczelni.

Pomiar jakości kształcenia w zakresie szkolnictwa wyższego na podstawie danych marketingowych jest bardzo złożonym procesem. Przedstawione badania są przykładem pomiaru satysfakcji jednej z grup klientów uczelni - studentów, ale powinno się również analizować satysfakcję innych grup klientów szkół wyższych (studentów i ich rodziców, przyszłych pracodawców oraz nauczycieli akademickich). Analizą powinni zostać objęci także absolwenci danej uczelni, którzy mogą ocenić efekty kształcenia i przydatność zdobytej wiedzy i umiejętności.

\section{Literatura}

Brzeziński J. [2004], Metodologia badań psychologicznych, wyd. 5, Wydawnictwo Naukowe PWN, Warszawa.

Bugdol M. [2008], Zarzqdzanie jakościq w urz̨̨ach administracji publicznej. Teoria i praktyka, wyd. 1, Difin, Warszawa.

Choudhury K. [2011], A Model of Service Quality in the Education Service, www.iimcal. ac.in/research/Download/education-Koushiki.pdf (dostęp: 15.01.2011).

Hamrol A. [2007], Zarzq̨dzanie jakościq z przykładami, wyd. 2 zm., Wydawnictwo Naukowe PWN, Warszawa.

Jakość w badaniach i dydaktyce szkół wyższych, red. S. Doroszewicz i A. Kobylińska [2007], Oficyna Wydawnicza SGH, Warszawa.

Kitchroen K. [2004], Literature Review: Service Quality in Educational Institutions, „ABAC Journal”, vol. 24, nr 2, www.journal.au.edu/abac_journal/2004/may04/abacvol24no2_artical02.pdf (dostęp: 7.01.2011).

Kolman R. [2009], Kwalitologia - wiedza o różnych dziedzinach jakości, wyd. 1, Wydawnictwo Placet, Warszawa.

Lewis R. [2004], Importance-Performance Analysis, ,Australasian Journal of Engineering", vol. 2, www.aaee.com.au/journal/2004/lewis04.pdf (dostęp: 12.02.2011).

Łuczak J., Matuszak-Flejszman A. [2007], Metody i techniki zarzqdzania jakościq, wyd. 1, Wydawnictwo Quality Progress, Poznań.

Martilla J.A., James J.C. [1977], Importance-Performance Analysis, ,Journal of Marketing", vol. 41. 
Parasuraman A., Zeithaml V.A., Berry L.L. [1985], A Conceptual Model of Service Quality and Its Implications for Future Research, ,Journal of Marketing”, vol. 49.

Parasuraman A., Zeithaml V. A., Berry L.L. [1990], Delivering Quality Service. Balancing Customer Perceptions and Expectations, 1st ed., The Free Press, New York.

Przybylski W., Rudnicki S., Szwed A. [2010], Ewaluacja jakości dydaktyki w szkolnictwie wyższym. Metody, narzędzia, dobre praktyki, wyd. 1, Wydawnictwo Wyższej Szkoły Europejskiej, Kraków.

Sagan A. [2003], Skale jako podstawowy instrument pomiaru $w$ badaniach satysfakcji i lojalności, www.statsoft.pl/czytelnia/marketing/skale.pdf (dostęp: 2.12.2010).

Sztejnberg A. [2008], Doskonalenie usług edukacyjnych. Podstawy pomiaru jakości kształcenia, wyd. 1, Wydawnictwo Uniwersytetu Opolskiego, Opole.

Sztejnberg A., Stypułkowska M. [2005], Ocena względnej ważności wymiarów SERVQUAL jako metoda wspomagania jakości ksztatcenia w szkole wyższej [w:] Media i metody wspomagające jakość kształcenia, red. K. Jankowski, B. Sitarska i C. Tkaczuk, Wydawnictwo Akademii Podlaskiej, Siedlce, www.inp.uni.opole.pl/ sztejnberg/komspol/ocena.pdf (dostęp: 27.01.2011).

Sztejnberg A., Stypułkowska M., Hurek J. [2005], Zastosowanie modelu SERVQUAL w mierzeniu jakości usług edukacyjnych [w:] Aktuálni otázky výuky chemie / Actual Questions of Chemistry Education, red. M. Bilek, Hradec Králové, www.inp.uni. opole.pl/ sztejnberg/komspol/servqual.pdf (dostęp: 27.01.2011).

\section{Methods for Measuring Quality in Higher Education}

The aim of this article is to present marketing methods of measuring the quality of higher education. The article consists of two parts. The first concerns theoretical issues about quality and quality service of higher education. The second presents two methods of measuring quality service in higher education (SERVQUAL, IPA).

Keywords: quality in higher education, higher education, SERVQUAL, IPA. 